\title{
Shewanella irciniae sp. nov., a novel member of the family Shewanellaceae, isolated from the marine sponge Ircinia dendroides in the Bay of Villefranche, Mediterranean Sea
}

Correspondence Pei-Yuan Qian boqianpy@ust.hk

\author{
On On Lee, ${ }^{1}$ Stanley C. K. Lau, ${ }^{2}$ Mandy M. Y. Tsoi, ${ }^{1}$ Xiancui Li, ${ }^{1}$ \\ loulia Plakhotnikova, ${ }^{1}$ Sergey Dobretsov, ${ }^{1}$ Madeline C. S. Wu, ${ }^{1}$ \\ Po-Keung Wong, ${ }^{3}$ Markus Weinbauer ${ }^{4}$ and Pei-Yuan Oian ${ }^{1}$
}

${ }^{1}$ Coastal Marine Laboratory/Department of Biology, The Hong Kong University of Science and Technology, Clear Water Bay, Kowloon, Hong Kong SAR, People's Republic of China

${ }^{2}$ Division of Environmental Science and Engineering, The National University of Singapore, Singapore

${ }^{3}$ Department of Biology, The Chinese University of Hong Kong, Shatin, N. T., Hong Kong SAR, People's Republic of China

${ }^{4}$ Microbial Ecology and Biogeochemistry Group, Laboratoire d'Océanographie de Villefranchesur-Mer, Villefranche-sur-Mer, France

\begin{abstract}
Strain UST04031 7-058 ${ }^{\top}$, comprising non-pigmented, rod-shaped, facultatively anaerobic, Gramnegative cells that are motile by means of single polar flagella, was isolated from the surface of a marine sponge (Ircinia dendroides) collected from the Mediterranean Sea. Comparative 16S rRNA gene sequence-based phylogenetic analysis placed the strain in a separate cluster with the recognized bacterium Shewanella algae IAM $14159^{\top}$, with which it showed a sequence similarity of $95.0 \%$. The sequence similarity between strain UST040317-058 ${ }^{\top}$ and its other (six) closest relatives ranged from 91.6 to $93.8 \%$. Strain UST040317-058 ${ }^{\top}$ showed oxidase, catalase and gelatinase activities. The typical respiratory quinones for shewanellas, menaquinone MK-7 and ubiquinones Q-7 and Q-8, were also detected. The predominant fatty acids in strain UST040317$058^{\top}$ were $15: 0,16: 0,17: 1 \omega 8 \mathrm{c}$ and summed feature 3 (comprising $115: 02-\mathrm{OH}$ and/or $16: 1 \omega 7 \mathrm{c}$ ), altogether representing $56 \cdot 9 \%$ of the total. The DNA G + C content was $39.9 \mathrm{~mol} \%$. The strain could be differentiated from other Shewanella species by its inability to reduce nitrate or produce $\mathrm{H}_{2} \mathrm{~S}$ and by 10-22 additional phenotypic characteristics. On the basis of the phylogenetic and phenotypic data presented in this study, strain UST040317-058 ${ }^{\top}$ represents a novel species in the genus Shewanella, for which the name Shewanella irciniae sp. nov. is proposed. The type strain is UST040317-058 $\left(=\mathrm{JCM} 13528^{\top}=\right.$ NRRL B-41466 $\left.{ }^{\top}\right)$.
\end{abstract}

The family Shewanellaceae was established from the emended description of a group of marine Alteromonaslike bacteria because of their deep phylogenetic branching and lack of association with any other genus in the family Alteromonadaceae (Ivanova et al., 2004c). At present, the family Shewanellaceae includes only one genus, Shewanella (MacDonell \& Colwell, 1985), which was created from the reclassification of two species previously assigned to the genus Alteromonas, namely [Alteromonas] putrefaciens (Lee

\footnotetext{
The GenBank/EMBL/DDBJ accession number for the 16S rRNA gene sequence of strain UST040317-058 ${ }^{\top}$ is DQ180743.

A scanning electron micrograph of cells of strain UST040317-058 ${ }^{\top}$ is available as a supplementary figure in IJSEM Online.
}

et al., 1981) and [Alteromonas] hanedai (Jensen et al., 1980). Shewanella species comprise Gram-negative, straight or curved rod-shaped, aerobic or facultatively anaerobic and readily cultivated gammaproteobacteria isolated from diverse sources, including activated sludge (Xu et al., 2005), marine invertebrates (Ivanova et al., 2004b), red algae (Simidu et al., 1990), a tidal flat (Yoon et al., 2004a), seawater (Ivanova et al., 2001, 2004a; Yoon et al., 2004b), sediments (Venkateswaran et al., 1998) and clinical samples (Levin, 1972; Debois et al., 1975; Holmes et al., 1975). In the last decade, the number of recognized species in this genus has increased; they have been studied extensively because of their capacity for dissimilatory reduction of manganese and iron oxides (Myers \& Nealson, 1988; Bowman et al., 1997; Venkateswaran et al., 1998), for co-metabolization of 
halogenated organic pollutants (Petrovskis et al., 1994), for the destructive souring of crude petroleum (Semple \& Westlake, 1987) and for the production of tetrodotoxin (Simidu et al., 1990) and large proportions of polyunsaturated fatty acids (Bowman et al., 1997; Russell \& Nichols, 1999; Ivanova et al., 2004a). At the time of writing, there are more than 30 Shewanella species with validly published names. On the basis of the polyphasic taxonomic data presented in this study, we propose a novel member of this genus, strain UST040317-058 ${ }^{\mathrm{T}}$, isolated in March 2004 from the surface of a marine sponge (Ircinia dendroides) found associated with sea-grass (Posidonia) in the Bay of Villefranche in the Mediterranean Sea.

Strain UST040317-058 ${ }^{\mathrm{T}}$ was isolated using a standard dilution plating technique on a marine agar medium containing $3 \mathrm{~g}$ yeast extract (Oxoid), $5 \mathrm{~g}$ peptone (Oxoid) and $12 \mathrm{~g}$ bacteriological agar (Oxoid) in $110.22 \mu \mathrm{m}$ filtered seawater at $32 \%$ salinity after $48 \mathrm{~h}$ incubation at $28^{\circ} \mathrm{C}$. Unless otherwise indicated, all characteristics described hereafter are based on cultures grown on marine agar under these conditions. Colonies of strain UST040317- $058^{\mathrm{T}}$ were milky, raised and circular $(0 \cdot 8-$ $1.5 \mathrm{~mm}$ in diameter) with entire edges and a smooth surface (as observed under a Leica MZ6 light microscope at $40 \times$ magnification). Gram stain was determined using light microscopy according to Smibert \& Krieg (1994). Cell morphology was examined using scanning electron microscopy (6700F; JEOL) according to Neu et al. (2001) and the presence of flagella was determined by transmission electron microscopy according to Allan et al. (2002). Gliding motility was observed under a phase-contrast light microscope (BX51; Olympus) at $100 \times$ magnification using cells grown on quarter-strength marine broth 2216 (Oxoid) solidified with $1.2 \%$ agar according to Bowman (2000). Strain UST040317- $058^{\mathrm{T}}$ comprised Gram-negative, rod-shaped cells that were motile by means of a single polar flagellum (see Supplementary Fig. S1 available in IJSEM Online).

The almost-complete 16S rRNA gene sequence of strain UST040317-058 $8^{\mathrm{T}}$ (1462 bp) was obtained bidirectionally with three replicates, as described by Lau et al. (2004). Comparative analysis of the $16 \mathrm{~S}$ rRNA gene sequence with sequences deposited in GenBank using BLAST indicated that the strain belonged to the family Shewanellaceae and showed the highest sequence similarity $(95.0 \%)$ with Shewanella algae IAM $14159^{\mathrm{T}}$ (Simidu et al., 1990). The $16 \mathrm{~S}$ rRNA gene sequence was automatically, and then manually, aligned with a database of $>30000$ previously aligned 16S rRNA gene sequences by using the ARB software package (Ludwig et al., 2004). Phylogenetic trees were constructed using three different methods: neighbour-joining, maximum-likelihood and maximum-parsimony. The neighbour-joining phylogenetic tree (Fig. 1) placed strain UST040317-058

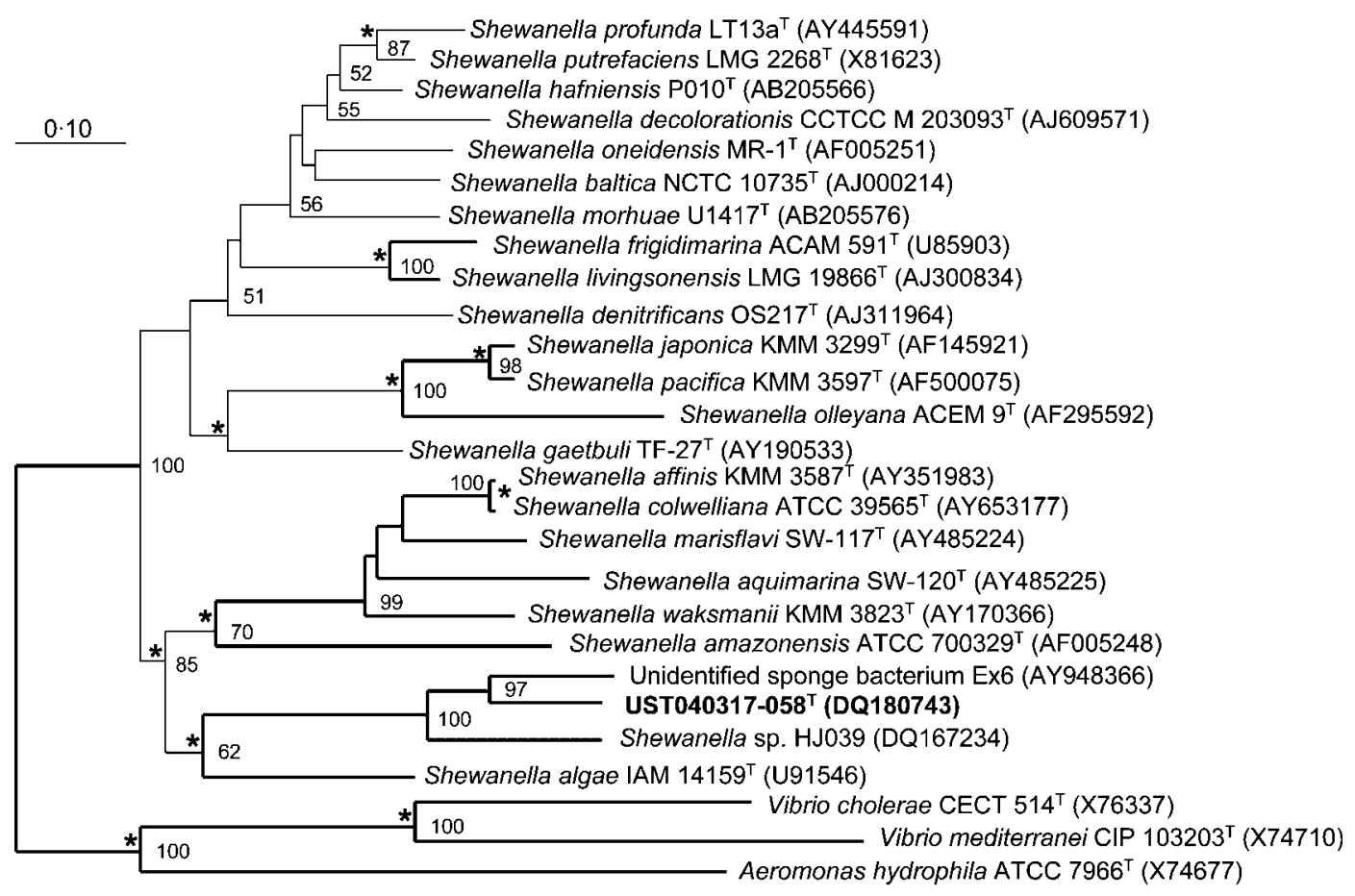

Fig. 1. Neighbour-joining tree, based on $16 \mathrm{~S}$ rRNA gene sequence comparisons, showing the estimated phylogenetic relationships between UST040317-058 ${ }^{\top}$ and related species. Strains belonging to the genera Vibrio and Aeromonas were chosen as the outgroups. Asterisks indicate nodes that are also found in the maximum-parsimony tree; bold lines indicate branches that are also found in the maximum-likelihood tree. Bootstrap values greater than $50 \%$, expressed as a percentage of 500 replicates, are shown at the nodes. GenBank accession numbers are shown in parentheses. Bar, 1 nucleotide substitution per 100 nucleotides. 
within a cluster of two undescribed bacteria which were also isolated from marine sponges: an unidentified sponge bacterium, strain Ex6 (Wichels et al., 2006), and Shewanella species strain HJ039 (GenBank accession no. DQ167234). This cluster, together with the recognized species $S$. algae IAM $14159^{\mathrm{T}}$, formed a distinct clade that clustered robustly with another clade comprising six other Shewanella species with validly published names, including Shewanella amazonensis SB2B ${ }^{\mathrm{T}}$ (Venkateswaran et al., 1998), Shewanella waksmanii KMM $3823^{\mathrm{T}}$ (Ivanova et al., 2003), Shewanella aquimarina $\mathrm{SW}-120^{\mathrm{T}}$ (Yoon et al., 2004b), Shewanella marisflavi SW $-117^{\mathrm{T}}$ (Yoon et al., 2004b), Shewanella colwelliana ATCC $39565^{\mathrm{T}}$ (Coyne et al., 1989) and Shewanella affinis KMM $3587^{\mathrm{T}}$ (Ivanova et al., 2004b). These species shared $91 \cdot 6-93 \cdot 8 \% 16 \mathrm{~S}$ rRNA gene sequence similarity with strain UST040317-058 ${ }^{\mathrm{T}}$. The maximum-likelihood and maximum-parsimony trees based on cladistic methods (i.e. character-based) showed similar topography for the novel strain and the Shewanella species. These results support the inclusion of UST040317-058 ${ }^{\mathrm{T}}$ as a novel species in the genus Shewanella.

The cellular fatty acid profile of strain UST040317- $058^{\mathrm{T}}$ was determined using the Sherlock Microbial Identification System (MIDI) according to the manufacturer's protocol. Strain UST040317-058 $8^{\mathrm{T}}$ had a cellular fatty acid profile dominated by the saturated straight-chain fatty acid 16:0 $(13.0 \%)$, the saturated branched-chain fatty acid i15:0 $(14 \cdot 1 \%)$, the unsaturated straight-chain fatty acid $17: 1 \omega 8 \mathrm{c}$ $(13.3 \%)$ and summed feature 3 (comprising i15:0 2-OH and/or $16: 1 \omega 7 c)(16.5 \%)$, which together constituted $56.9 \%$ of the total fatty acid content (Table 1 ). These fatty acids are common to Shewanella species, supporting the inclusion of strain UST040317-058 ${ }^{\mathrm{T}}$ in the genus. However, some fatty acids that were common in some

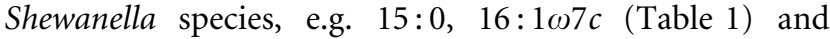
polyunsaturated fatty acids (Bowman et al., 1997; Skerratt et al., 2002; Ivanova et al., 2004a), were not observed in strain UST040317-058 ${ }^{\mathrm{T}}$, suggesting that this novel isolate is unique.

The DNA G+C content of UST040317-058 ${ }^{\mathrm{T}}$ was $40 \cdot 0 \pm 0 \cdot 1 \mathrm{~mol} \%(n=3)$ as determined using an HPLC method according to Mesbah et al. (1989). This value is within the range of $\mathrm{G}+\mathrm{C}$ contents observed among members of the genus Shewanella $(39 \cdot 0-54 \cdot 0 \mathrm{~mol} \%)$ (Table 2). The presence of respiratory quinones was checked using an HPLC method according to Collins (1994). Menaquinones extracted from Cellulophaga lytica (Nakagawa \& Yamasato, 1993) and Pedobacter heparinus (Steyn et al., 1998) served as references for MK-6 and MK-7, respectively, while ubiquinones extracted from Escherichia coli strain XL1-Blue (Gao et al., 2004) served as references for Q-7 and Q-8. MK-7, Q-7 and Q-8, but not MK-6, were detected in strain UST040317-058 ${ }^{\mathrm{T}}$.

The oxygen requirement for growth was investigated using the Oxoid Anaerobic System. Growth at different temperatures $\left(4,12,20,28,36,44\right.$ and $\left.52^{\circ} \mathrm{C}\right)$ and $\mathrm{pH}(5,6,7,8,9$ and
10) was monitored on marine agar incubated for up to 10 days. The $\mathrm{NaCl}$ requirement for growth was tested on a $1.2 \%$ agar medium containing $5 \mathrm{~g}$ peptone, $5 \mathrm{~g} \mathrm{MgCl}_{2}, 2 \mathrm{~g}$ $\mathrm{MgSO}_{4}, 1 \mathrm{~g} \mathrm{KCl}, 0 \cdot 5 \mathrm{~g} \mathrm{CaCl}_{2}$ and different amounts of $\mathrm{NaCl}$ (from 0 up to $180 \mathrm{~g}$ ) and the $\mathrm{pH}$ was adjusted to $7 \cdot 5$ using $\mathrm{KOH}$ (Isnansetyo \& Kamei, 2003). Haemolytic activity was studied on blood agar containing $40 \mathrm{~g}$ blood agar base (Oxoid), $50 \mathrm{ml}$ rabbit blood and $950 \mathrm{ml} 0 \cdot 22 \mu \mathrm{m}$-filtered seawater (Ivanova et al., 2004b). Susceptibility to the antibiotics streptomycin, benzylpenicillin, chloramphenicol, ampicillin, tetracycline and kanamycin was tested using standard agar disc diffusion assays according to Acar (1980). The amounts of antibiotic tested ranged from 1.0 to $100 \cdot 0 \mu \mathrm{g}$ per disc. The hydrolysis of casein and cellulose was investigated according to Norris et al. (1985) and Bowman (2000), respectively. The hydrolysis of Tweens 20,40 and 80 and of chitin was tested as described in Baumann \& Baumann (1981). The hydrolysis of agar, DNA and starch and the production of oxidase and catalase were determined according to Smibert \& Krieg (1994). Other enzymic activities, the utilization of (and acid production from) different carbon sources, the reduction of nitrate and the production of $\mathrm{H}_{2} \mathrm{~S}$, indole and acetoin were tested using the commercial systems API 20E, API 20NE, API $50 \mathrm{CH}$, API ZYM (bioMérieux) and MicroLog 3 (Biolog) according to the manufacturers' manuals, except that the cells used for the API system were suspended in sterile seawater at $22 \%$ salinity before inoculation (MacDonell et al., 1982). Growth on glycerol, D-glucose, sucrose, D-mannitol, D-galactose, starch, D-sorbitol, D-arabinose and D-melibiose as sole carbon sources was also tested on a $1.2 \%$ agar medium containing $0 \cdot 2 \mathrm{~g} \mathrm{NaNO}_{3}, 0 \cdot 2 \mathrm{~g} \mathrm{NH}_{4} \mathrm{Cl}, 0 \cdot 05$ g yeast extract and $4 \%(\mathrm{w} / \mathrm{v})$ carbon source in 11 seawater at $35 \%$ salinity (Nedashkovskaya et al., 2003). Detailed physiological and biochemical characteristics of UST040317- $058^{\mathrm{T}}$ are given in the species description below.

Strain UST040317-058 ${ }^{\mathrm{T}}$ can be differentiated from its closest relative, S. algae IAM $14159^{\mathrm{T}}$, by means of several phenotypic characteristics, including the inability of the novel strain to reduce nitrate, produce $\mathrm{H}_{2} \mathrm{~S}$, grow at $8 \%$ $\mathrm{NaCl}$ and $40^{\circ} \mathrm{C}$, produce lipase or utilize D-maltose, DLlactate, DL-malate, succinate, fumarate and L-serine and its ability to utilize D-galactose, D-glucose, D-mannitol and Dsorbitol as sole carbon sources. The novel strain is differentiated from other selected Shewanella species in Table 2. On the basis of the phylogenetic evidence together with the phenotypic characteristics presented in this study, strain UST040317-058 ${ }^{\mathrm{T}}$ represents a novel species within the genus Shewanella, for which the name Shewanella irciniaesp. nov. is proposed.

\section{Description of Shewanella irciniae sp. nov.}

Shewanella irciniae (ir.ci'ni.ae. N.L. gen. n. irciniae of/from Ircinia, isolated from the marine sponge Ircinia dendroides).

Cells are Gram-negative, short, straight rods $(1 \cdot 3-2 \cdot 0 \mu \mathrm{m}$ in length and $0.5 \mu \mathrm{m}$ in width) and are motile by means of a 
Table 1. Cellular fatty acid content of strain UST040317-058 ${ }^{\top}$ and its close relatives in the genus Shewanella

Strains: 1, UST040317-058 ${ }^{\mathrm{T}}$; 2, S. algae IAM $14159^{\mathrm{T}}$ (data from Simidu et al., 1990); 3, S. amazonensis SB2B ${ }^{\mathrm{T}}$ (Venkateswaran et al., 1998);

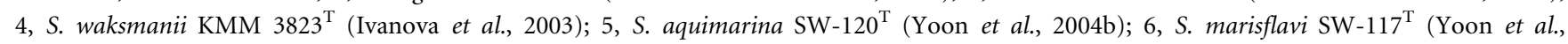
2004b); 7, S. colwelliana ATCC $39565^{\mathrm{T}}$ (Coyne et al., 1989); 8, S. affinis KMM $3587^{\mathrm{T}}$ (Ivanova et al., 2004b). Values given are mean percentages of the total fatty acid content. The prefixes ' $\mathrm{i}$ ' and ' $a$ ' indicate iso-branched and anteiso-branched fatty acids, respectively. Fatty acids representing $<0 \cdot 2 \%$ in all rows have been excluded. - , Not detected.

\begin{tabular}{|c|c|c|c|c|c|c|c|c|}
\hline Fatty acid & 1 & 2 & 3 & 4 & 5 & 6 & 7 & 8 \\
\hline \multicolumn{9}{|c|}{ Saturated straight-chain fatty acids } \\
\hline $12: 0$ & $1 \cdot 8$ & - & - & $2 \cdot 0$ & $1 \cdot 9$ & $1 \cdot 6$ & $1 \cdot 0$ & $3 \cdot 3$ \\
\hline $13: 0$ & $1 \cdot 2$ & - & - & - & $0 \cdot 9$ & $0 \cdot 5$ & $3 \cdot 1$ & $2 \cdot 1$ \\
\hline $14: 0$ & $2 \cdot 0$ & $1 \cdot 3$ & $1 \cdot 4$ & $1 \cdot 7$ & $1 \cdot 3$ & $1 \cdot 5$ & $1 \cdot 9$ & $1 \cdot 6$ \\
\hline $15: 0$ & - & $6 \cdot 5$ & $9 \cdot 2$ & $5 \cdot 3$ & $4 \cdot 4$ & $4 \cdot 1$ & $14 \cdot 0$ & $6 \cdot 7$ \\
\hline $16: 0$ & $13 \cdot 0$ & $16 \cdot 8$ & $6 \cdot 1$ & $6 \cdot 2$ & $11 \cdot 6$ & $14 \cdot 5$ & $8 \cdot 7$ & $11 \cdot 0$ \\
\hline $17: 0$ & $4 \cdot 4$ & $4 \cdot 1$ & $4 \cdot 0$ & - & $1 \cdot 7$ & $1 \cdot 9$ & $5 \cdot 1$ & $4 \cdot 2$ \\
\hline $18: 0$ & $0 \cdot 9$ & $0 \cdot 4$ & $0 \cdot 1$ & $0 \cdot 3$ & - & - & $0 \cdot 5$ & $0 \cdot 6$ \\
\hline \multicolumn{9}{|c|}{ Unsaturated straight-chain fatty acids } \\
\hline $15: 1 \omega 8 c$ & $0 \cdot 6$ & - & - & - & - & - & $1 \cdot 0$ & $0 \cdot 7$ \\
\hline $15: 1 \omega 6 c$ & $1 \cdot 1$ & $0 \cdot 2$ & $0 \cdot 8$ & - & - & - & $2 \cdot 4$ & $1 \cdot 1$ \\
\hline $16: 1 \omega 9 c$ & $1 \cdot 5$ & $2 \cdot 8$ & $0 \cdot 7$ & - & $0 \cdot 7$ & $0 \cdot 7$ & - & - \\
\hline $16: 1 \omega 7 c$ & - & $15 \cdot 3$ & $14 \cdot 7$ & $9 \cdot 8$ & - & - & $19 \cdot 1$ & $26 \cdot 5$ \\
\hline $17: 1 \omega 8 c$ & $13 \cdot 3$ & $10 \cdot 9$ & $23 \cdot 5$ & - & $6 \cdot 7$ & $5 \cdot 3$ & $17 \cdot 0$ & $19 \cdot 0$ \\
\hline $17: 1 \omega 6 c$ & $1 \cdot 9$ & $0 \cdot 9$ & $2 \cdot 4$ & - & $0 \cdot 8$ & $0 \cdot 6$ & $0 \cdot 7$ & $2 \cdot 1$ \\
\hline $18: 1 \omega 9 c$ & $4 \cdot 2$ & $5 \cdot 0$ & $1 \cdot 4$ & - & $1 \cdot 6$ & $1 \cdot 7$ & $0 \cdot 9$ & $2 \cdot 8$ \\
\hline $18: 1 \omega 7 c$ & $3 \cdot 7$ & $5 \cdot 2$ & $4 \cdot 5$ & $2 \cdot 0$ & $3 \cdot 4$ & $4 \cdot 1$ & $0 \cdot 8$ & $6 \cdot 1$ \\
\hline $20: 4 \omega 5 c$ & - & - & - & $6 \cdot 7$ & - & - & - & - \\
\hline $20: 5 \omega 3 c$ & - & - & - & - & - & - & $0 \cdot 4$ & - \\
\hline \multicolumn{9}{|c|}{ Hydroxy straight-chain fatty acids } \\
\hline $11: 03-\mathrm{OH}$ & $0 \cdot 7$ & - & - & - & - & - & - & - \\
\hline $12: 03-\mathrm{OH}$ & $4 \cdot 3$ & - & - & - & $0 \cdot 8$ & $1 \cdot 3$ & - & - \\
\hline \multicolumn{9}{|c|}{ Saturated branched fatty acids } \\
\hline i11:0 & $0 \cdot 3$ & - & - & - & $0 \cdot 1$ & $2 \cdot 0$ & - & - \\
\hline i13: 0 & $2 \cdot 3$ & $0 \cdot 5$ & $4 \cdot 7$ & $10 \cdot 0$ & $7 \cdot 4$ & $5 \cdot 9$ & $6 \cdot 6$ & 1.9 \\
\hline i14:0 & $1 \cdot 0$ & $1 \cdot 4$ & $1 \cdot 6$ & - & $0 \cdot 9$ & $0 \cdot 7$ & $0 \cdot 5$ & $1 \cdot 8$ \\
\hline i15:0 & $14 \cdot 1$ & $27 \cdot 4$ & $26 \cdot 7$ & $32 \cdot 5$ & $27 \cdot 5$ & $22 \cdot 9$ & $13 \cdot 8$ & $25 \cdot 2$ \\
\hline $\mathrm{a} 15: 0$ & $0 \cdot 1$ & - & - & - & - & - & $0 \cdot 2$ & $0 \cdot 3$ \\
\hline i16:0 0 & $0 \cdot 4$ & $0 \cdot 5$ & $1 \cdot 4$ & - & $0 \cdot 4$ & $0 \cdot 2$ & - & $0 \cdot 6$ \\
\hline i17:0 & $0 \cdot 8$ & $1 \cdot 4$ & $1 \cdot 8$ & - & $1 \cdot 9$ & $1 \cdot 6$ & $1 \cdot 9$ & $0 \cdot 8$ \\
\hline \multicolumn{9}{|c|}{ Unsaturated branched fatty acids } \\
\hline a15: 1 & - & - & - & - & - & - & $1 \cdot 0$ & - \\
\hline \multicolumn{9}{|c|}{ Hydroxy branched fatty acids } \\
\hline $\mathrm{i} 13: 03-\mathrm{OH}$ & $5 \cdot 0$ & - & - & - & $5 \cdot 1$ & $4 \cdot 5$ & - & - \\
\hline Summed feature $1^{\star}$ & $1 \cdot 9$ & - & - & - & $0 \cdot 6$ & $0 \cdot 5$ & - & - \\
\hline Summed feature $2 \dagger$ & $1 \cdot 2$ & - & - & - & $0 \cdot 9$ & $0 \cdot 9$ & - & - \\
\hline Summed feature $3 \ddagger$ & $16 \cdot 5$ & - & - & - & $15 \cdot 9$ & $18 \cdot 6$ & - & - \\
\hline
\end{tabular}

*Summed feature 1 comprises $13: 03-\mathrm{OH}$ and/or i15: 1 .

$\dagger$ Summed feature 2 comprises 14:0 3-OH and/or i16: 1 .

$\ddagger$ Summed feature 3 comprises i15:0 2-OH and/or $16: 1 \omega 7 c$.

single polar flagellum. Facultatively anaerobic. When cultivated on marine agar at $28^{\circ} \mathrm{C}$ for $48 \mathrm{~h}$, colonies are milky, $0 \cdot 8-1 \cdot 5 \mathrm{~mm}$ in diameter, circular and raised with a smooth surface and an entire edge. Does not produce diffusible pigments. Optimal growth occurs at $20-28^{\circ} \mathrm{C}$, but no growth occurs at temperatures lower than $12{ }^{\circ} \mathrm{C}$ or higher than $36^{\circ} \mathrm{C}$. Growth occurs at $\mathrm{pH} 6-10$, but no growth occurs at or below pH 5. Requires $\mathrm{NaCl}(2 \cdot 0-6 \cdot 0 \%$; optimum, $2 \cdot 0-4 \cdot 0 \%$ ) for growth. MK-7, Q-7 and Q-8 are the predominant respiratory quinones detected. The

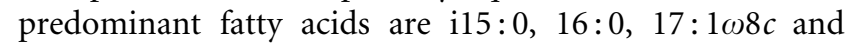
summed feature 3 (comprising i15:0 2-OH and/or 
Table 2. Phenotypic characteristics that differentiate strain UST040317-058 ${ }^{\top}$ from the seven most closely related members of the genus Shewanella

Strains: 1, UST040317-058 ${ }^{\mathrm{T}}$; 2, S. algae IAM $14159^{\mathrm{T}}$ (data from Simidu et al., 1990); 3, S. amazonensis SB2B ${ }^{\mathrm{T}}$ (Venkateswaran et al., 1998); 4, S. waksmanii KMM $3823^{\mathrm{T}}$ (Ivanova et al., 2003); 5, S. aquimarina SW- $120^{\mathrm{T}}$ (Yoon et al., 2004b); 6, S. marisflavi SW- $117^{\mathrm{T}}$ (Yoon et al., 2004b); 7, S. colwelliana ATCC $39565^{\mathrm{T}}$ (Coyne et al., 1989); 8, S. affinis KMM $3587^{\mathrm{T}}$ (Ivanova et al., 2004b). All strains are straight rods, Gram-negative, facultatively anaerobic and motile by means of a single polar flagellum. All are positive for haemolytic activity and the production of gelatinase, oxidase and catalase. All are negative for the production of arginine dihydrolase, lysine decarboxylase, ornithine decarboxylase and indole and for the utilization of lactose. +, Positive; -, negative; ND, not determined.

\begin{tabular}{|c|c|c|c|c|c|c|c|c|}
\hline Characteristic & 1 & 2 & 3 & 4 & 5 & 6 & 7 & 8 \\
\hline $\begin{array}{l}\text { DNA G }+ \text { C content } \\
(\mathrm{mol} \%)\end{array}$ & 40 & 54 & 52 & 43 & 54 & 51 & 46 & 45 \\
\hline Pigment of cell biomass & - & - & - & $+^{*}$ & - & - & - & - \\
\hline \multicolumn{9}{|l|}{ Growth at/with: } \\
\hline $4^{\circ} \mathrm{C}$ & - & - & + & + & - & + & + & - \\
\hline $28^{\circ} \mathrm{C}$ & + & + & + & + & + & + & ND & + \\
\hline $40^{\circ} \mathrm{C}$ & - & + & + & - & + & + & - & - \\
\hline $0 \% \mathrm{NaCl}$ & - & - & + & - & - & + & - & - \\
\hline $6 \% \mathrm{NaCl}$ & + & + & - & + & + & + & - & + \\
\hline $8 \% \mathrm{NaCl}$ & - & + & - & - & + & + & - & - \\
\hline $\mathrm{pH}$ range & $6-10$ & $6-10$ & $6-10$ & $6-10$ & $5-8$ & $5-8$ & ND & ND \\
\hline $\begin{array}{l}\text { Reduction of } \mathrm{NO}_{3} \\
\text { to } \mathrm{NO}_{2}\end{array}$ & - & + & + & + & + & + & + & + \\
\hline \multicolumn{9}{|l|}{ Hydrolysis of: } \\
\hline Casein & - & ND & ND & - & + & + & ND & + \\
\hline Chitin & - & - & - & - & $\mathrm{ND}$ & $\mathrm{ND}$ & - & - \\
\hline Tween 40 & - & ND & - & + & - & - & ND & + \\
\hline Tween 80 & - & ND & - & - & + & + & ND & + \\
\hline \multicolumn{9}{|l|}{ Production of: } \\
\hline Amylase & - & - & - & - & + & - & + & - \\
\hline $\mathrm{H}_{2} \mathrm{~S}$ & - & + & + & + & + & + & ND & + \\
\hline Lipase & - & + & - & + & + & + & + & + \\
\hline \multicolumn{9}{|l|}{ Utilization of: } \\
\hline D-Cellobiose & - & - & ND & - & - & + & ND & $\mathrm{ND}$ \\
\hline D-Fructose & - & - & + & - & - & - & - & - \\
\hline Fumarate & - & + & + & - & - & - & + & - \\
\hline D-Galactose & + & - & + & - & + & - & - & - \\
\hline D-Glucose & + & - & $\mathrm{ND}$ & + & - & + & ND & + \\
\hline Glycerol & + & + & - & - & - & - & - & - \\
\hline DL-Lactate & - & + & + & - & + & + & - & - \\
\hline DL-Malate & - & + & - & ND & + & + & - & ND \\
\hline D-Maltose & - & + & - & ND & + & + & - & ND \\
\hline D-Mannitol & + & - & - & ND & - & - & - & + \\
\hline D-Melibiose & + & - & ND & ND & - & - & ND & ND \\
\hline L-Serine & - & + & + & ND & $\mathrm{ND}$ & $\mathrm{ND}$ & ND & + \\
\hline D-Sorbitol & + & - & - & ND & - & - & - & ND \\
\hline Succinate & - & + & + & - & + & + & - & - \\
\hline Sucrose & + & + & - & - & - & - & - & - \\
\hline
\end{tabular}

${ }^{\star}$ The colour of the pigment was brown/greenish.
$16: 1 \omega 7 c$ ), together constituting $56.9 \%$ of the total. Susceptible to $1.0 \mu \mathrm{g}$ benzylpenicillin, $1.0 \mu \mathrm{g}$ chloramphenicol, $1.0 \mu \mathrm{g}$ ampicillin, $10 \cdot 0 \mu \mathrm{g}$ tetracycline and $100 \cdot 0 \mu \mathrm{g}$ streptomycin, but resistant to kanamycin (up to $100 \cdot 0 \mu \mathrm{g}$ tested). Gelatin is hydrolysed, but casein, agar, starch, chitin, cellulose and Tweens 20, 40 and 80 are not. Acetoin, indole and $\mathrm{H}_{2} \mathrm{~S}$ are not produced. Nitrate is not reduced. Citrate is not utilized. Positive for haemolytic activity, DNase, oxidase, catalase, alkaline phosphatase, esterase (C4), esterase lipase (C8), leucine arylamidase, valine arylamidase, acid phosphatase, naphthol-AS-BI-phosphohydrolase and $\alpha$-fucosidase. Negative for urease, lipase (C14), cystine arylamidase, trypsin, $\alpha$-chymotrypsin, $\alpha$ - and $\beta$-galactosidases, $\beta$-glucuronidase, $\alpha$ - and $\beta$-glucosidases, $N$-acetyl- $\beta$ glucosaminidase, $\alpha$-mannosidase, arginine dihydrolase, lysine decarboxylase, ornithine decarboxylase and tryptophan deaminase. Utilizes glycerol, D-glucose, sucrose, Dmannitol, D-galactose, starch, D-sorbitol, D-arabinose and D-melibiose as sole carbon sources on agar medium supplemented with $4 \%(\mathrm{w} / \mathrm{v})$ carbon source. Utilizes Dglucose, L-arabinose, aesculin ferric citrate and potassium 2ketogluconate in the API $50 \mathrm{CH}$ and 20NE systems. Utilizes $\alpha$ - and $\beta$-hydroxybutyric acids, methyl pyruvate and Dpsicose in the MicroLog 3 system. Other carbon sources included in the MicroLog 3, API 20NE and $50 \mathrm{CH}$ systems are not utilized. No acid production is observed from the carbon sources in the API $50 \mathrm{CH}$ and $20 \mathrm{E}$ systems.

The type strain, UST040317-058 ${ }^{\mathrm{T}}\left(=\mathrm{JCM} 13528^{\mathrm{T}}=\mathrm{NRRL}\right.$ $\mathrm{B}-41466^{\mathrm{T}}$ ), was isolated from the surface of a marine sponge (Ircinia dendroides) associated with Posidonia sea-grass in the Bay of Villefranche, Mediterranean Sea.

\section{Acknowledgements}

The authors thank Professor Hans G. Trüper (University of Bonn, Germany) and Professor Jean Euzéby (École Nationale Vétérinaire, France) for generous help with the Latin etymology, and Mr Ken Lau for respiratory quinone analysis. This work was supported by grants from the Research Grants Council (CA04/05.Sc01 and F-HK19/03T-II) to P.Y.Q.

\section{References}

Acar, J. F. (1980). The disc susceptibility test. In Antibiotics in Laboratory and Medicine, pp. 24-54. Edited by V. Lorian. Baltimore: Williams \& Wilkins.

Allan, V. J. M., Callow, M. E., Macaskie, L. E. \& Paterson-Beedle, M. (2002). Effect of nutrient limitation on biofilm formation and phosphatase activity of a Citrobacter sp. Microbiology 148, 277-288.

Baumann, P. \& Baumann, L. (1981). The marine gram-negative eubacteria: genera Photobacterium, Beneckea, Alteromonas, Pseudomonas and Alcaligenes. In The Prokaryotes, vol. 1, pp. 1302-1331. Edited by M. P. Starr, H. Stolp, H. G. Trüper, A. Balows \& H. Schlegel. Berlin: Springer.

Bowman, J. P. (2000). Description of Cellulophaga algicola sp. nov., isolated from the surfaces of Antarctic algae, and reclassification of Cytophaga uliginosa (ZoBell and Upham 1944) Reichenbach 1989 
as Cellulophaga uliginosa comb. nov. Int J Syst Evol Microbiol 50, 1861-1868.

Bowman, J. P., McCammon, S. A., Nichols, D. S., Skerratt, J. H., Rea, S. M., Nichols, P. D. \& McMeekin, T. A. (1997). Shewanella gelidimarina sp. nov. and Shewanella frigidimarina sp. nov., novel Antarctic species with the ability to produce eicosapentaenoic acid $(20: 5 \omega 3)$ and grow anaerobically by dissimilatory $\mathrm{Fe}(\mathrm{III})$ reduction. Int J Syst Bacteriol 47, 1040-1047.

Collins, M. D. (1994). Isoprenoid quinones. In Chemical Methods in Prokaryotic Systematics, pp. 265-310. Edited by M. Goodfellow \& A. G. O’Donnell. Chichester: Wiley.

Coyne, V. E., Pillidge, C. J., Sledjeski, D. D., Hori, H., Ortiz-Conde, B. A., Muir, D. G., Weiner, R. M. \& Colwell, R. R. (1989). Reclassification of Alteromonas colwelliana to the genus Shewanella by DNA-DNA hybridization, serology and 5S ribosomal RNA sequence data. Syst Appl Microbiol 12, 275-279.

Debois, J., Degreef, H., Vandepitte, J. \& Spaepen, J. (1975). Pseudomonas putrefaciens as a cause of infection in humans. J Clin Pathol 28, 993-996.

Gao, M., Liu, H., Yang, M., Hu, J. \& Shao, B. (2004). Indirect identification of isoprenoid quinones in Escherichia coli by LC-MS with atmospheric pressure chemical ionization in negative mode. J Basic Microbiol 44, 424-429.

Holmes, B., Lapage, S. P. \& Malnick, H. (1975). Strains of Pseudomonas putrefaciens from clinical material. J Clin Pathol 28, 149-155.

Isnansetyo, A. \& Kamei, Y. (2003). Pseudoalteromonas phenolica sp. nov., a novel marine bacterium that produces phenolic antimethicillin-resistant Staphylococcus aureus substances. Int J Syst Evol Microbiol 53, 583-588.

Ivanova, E. P., Sawabe, T., Gorshkova, N. M., Svetashev, V. I., Mikhailov, V. V., Nicolau, D. V. \& Christen, R. (2001). Shewanella japonica sp. nov. Int J Syst Evol Microbiol 51, 1027-1033.

Ivanova, E. P., Nedashkovskaya, O. I., Zhukova, N. V., Nicolau, D. V., Christen, R. \& Mikhailov, V. V. (2003). Shewanella waksmanii sp. nov., isolated from a sipuncula (Phascolosoma japonicum). Int J Syst Evol Microbiol 53, 1471-1477.

Ivanova, E. P., Gorshkova, N. M., Bowman, J. P., Lysenko, A. M., Zhukova, N. V., Sergeev, A. F., Mikhailov, V. V. \& Nicolau, D. V. (2004a). Shewanella pacifica sp. nov., a polyunsaturated fatty acidproducing bacterium isolated from sea water. Int $J$ Syst Evol Microbiol 54, 1083-1087.

Ivanova, E. P., Nedashkovskaya, O. I., Sawabe, T., Zhukova, N. V., Frolova, G. M., Nicolau, D. V., Mikhailov, V. V. \& Bowman, J. P. (2004b). Shewanella affinis sp. nov., isolated from marine invertebrates. Int J Syst Evol Microbiol 54, 1089-1093.

Ivanova, E. P., Flavier, S. \& Christen, R. (2004c). Phylogenetic relationships among marine Alteromonas-like proteobacteria: emended description of the family Alteromonadaceae and proposal of Pseudoalteromonadaceae fam. nov., Colwelliaceae fam. nov., Shewanellaceae fam. nov., Moritellaceae fam. nov., Ferrimonadaceae fam. nov., Idiomarinaceae fam. nov. and Psychromonadaceae fam. nov. Int J Syst Evol Microbiol 54, 1773-1788.

Jensen, M. J., Tebo, B. M., Baumann, P., Mandel, M. \& Nealson, K. H. (1980). Characterization of Alteromonas hanehai (sp. nov.), a nonfermentative luminous species of marine origin. Curr Microbiol 3, 311-315.

Lau, S. C. K., Tsoi, M. M. Y., Li, X., Plakhotnikova, I., Wu, M., Wong, P. K. \& Qian, P. Y. (2004). Loktanella hongkongensis sp. nov., a novel member of the $\alpha$-Proteobacteria originating from marine biofilms in Hong Kong waters. Int J Syst Evol Microbiol 54, 2281-2284.
Lee, J. V., Gibson, D. M. \& Shewan, J. M. (1981). Alteromonas putrefaciens sp. nov. In Validation of the Publication of New Names and New Combinations Previously Effectively Published Outside the IJSB, List no. 6. Int J Syst Bacteriol 31, 215-218.

Levin, R. E. (1972). Correlation of DNA base composition and metabolism of Pseudomonas putrefaciens isolates from food, human clinical specimens, and other sources. Antonie van Leeuwenhoek 38, 121-127.

Ludwig, W., Strunk, O., Westram, R. \& 29 other authors (2004). ARB: a software environment for sequence data. Nucleic Acids Res 32, 1363-1371.

MacDonell, M. T. \& Colwell, R. R. (1985). Phylogeny of the Vibrionaceae, and recommendation for two new genera, Listonella and Shewanella. Syst Appl Microbiol 6, 171-182.

MacDonell, M. T., Singleton, F. L. \& Hood, M. A. (1982). Diluent composition for use of API $20 \mathrm{E}$ in characterizing marine and estuarine bacteria. Appl Environ Microbiol 44, 423-427.

Mesbah, M., Premachandran, U. \& Whitman, W. (1989). Precise measurement of the $\mathrm{G}+\mathrm{C}$ content of deoxyribonucleic acid by highperformance liquid chromatography. Int J Syst Bacteriol 39, 159-167.

Myers, C. R. \& Nealson, K. H. (1988). Bacterial manganese reduction and growth with manganese oxide as the sole electron acceptor. Science 240, 1319-1321.

Nakagawa, Y. \& Yamasato, K. (1993). Phylogenetic diversity of the genus Cytophaga revealed by $16 \mathrm{~S}$ rRNA sequencing and menaquinone analysis. J Gen Microbiol 139, 1155-1161.

Nedashkovskaya, O. I., Kim, S. B., Hans, S. K. \& 7 other authors (2003). Mesonia algae gen. nov., sp. nov., a novel marine bacterium of the family Flavobacteriaceae isolated from the green alga Acrosiphonia sonderi (Kütz) Kornm. Int J Syst Evol Microbiol 53, 1967-1971.

Neu, B., Voigt, A., Mitlohner, R. \& 7 other authors (2001). Biological cells as templates for hollow microcapsules. J Microencapsul 18, 385-395.

Norris, J. R., Ribbons, D. W. \& Varma, A. K. (editors) (1985). Methods in Microbiology, vol. 18. London: Academic Press.

Petrovskis, E. A., Vogel, T. M. \& Adriaens, P. (1994). Effects of electron acceptors and donors on transformation of tetrachloromethane by Shewanella putrefaciens MR-1. FEMS Microbiol Lett 121, 357-364.

Russell, N. J. \& Nichols, D. S. (1999). Polyunsaturated fatty acids in marine bacteria - a dogma rewritten. Microbiology 145, 767-779.

Semple, K. M. \& Westlake, D. W. S. (1987). Characterization of ironreducing Alteromonas putrefaciens from oil field fluids. Can J Microbiol 33, 366-371.

Simidu, U., Kita-Tsukamoto, K., Yasumoto, K. \& Yotsu, M. (1990). Taxonomy of four marine bacterial strains that produce tetrodotoxin. Int J Syst Bacteriol 40, 331-336.

Skerratt, J. H., Bowman, J. P. \& Nichols, P. D. (2002). Shewanella olleyana sp. nov., a marine species isolated from a temperate estuary which produces high levels of polyunsaturated fatty acids. Int J Syst Evol Microbiol 52, 2101-2106.

Smibert, R. M. \& Krieg, N. R. (1994). Phenotypic characteristics. In Methods for General and Molecular Biology, pp. 607-654. Edited by P. Gerhardt, R. G. E. Murray, W. A. Wood \& N. R. Krieg. Washington, DC: American Society for Microbiology.

Steyn, P. L., Segers, P., Vancanneyt, M., Sandra, P., Kersters, K. \& Joubert, J. J. (1998). Classification of heparinolytic bacteria into a new genus, Pedobacter, comprising four species: Pedobacter heparinus comb. nov., Pedobacter piscium comb. nov., Pedobacter africanus sp. nov. and Pedobacter saltans sp. nov. Proposal of the family Sphingobacteriaceae fam. nov. Int J Syst Bacteriol 48, 165-177. 
Venkateswaran, K., Dollhopf, M. E., Aller, R., Stackebrandt, E. \& Nealson, K. H. (1998). Shewanella amazonensis sp. nov., a novel metal-reducing facultative anaerobe from Amazonian shelf muds. Int J Syst Bacteriol 48, 965-972.

Wichels, A., Würtz, S., Döpke, H., Schütt, C. \& Gerdts, G. (2006). Bacterial diversity in the breadcrumb sponge Halichondria panicea (Pallas). FEMS Microbiol Ecol 56, 102-118.

Xu, M., Guo, J., Cen, Y., Zhong, X., Cao, W. \& Sun, G. (2005). Shewanella decolorationis sp. nov., a dye-decolorizing bacterium isolated from activated sludge of a waste-water treatment plant. Int J Syst Evol Microbiol 55, 363-368.

Yoon, J. H., Kang, K. H., Oh, T. K. \& Park, Y. H. (2004a). Shewanella gaetbuli sp. nov., a slight halophile isolated from a tidal flat in Korea. Int J Syst Evol Microbiol 54, 487-491.

Yoon, J. H., Yeo, S. H., Kim, I. G. \& Oh, T. K. (2004b). Shewanella marisflavi sp. nov. and Shewanella aquimarina sp. nov., slightly halophilic organisms isolated from sea water of the Yellow Sea in Korea. Int J Syst Evol Microbiol 54, 2347-2352. 